\title{
PRO 2000, a broadly active anti-HIV sulfonated compound, inhibits viral entry by multiple mechanisms
}

\author{
Dana Huskens ${ }^{1}$, Albert T Profy ${ }^{2}$, Kurt Vermeire ${ }^{1}$, Dominique Schols ${ }^{1 *}$ \\ From $16^{\text {th }}$ International Symposium on HIV and Emerging Infectious Diseases \\ Marseille, France. 24-26 March 2010
}

\section{Background}

PRO 2000 is a polyanionic compound under development as a topical antimicrobial gel for the prevention of HIV-1 transmission. PRO 2000 is a synthetic naphthalene polymer which is documented to bind to HIV-1 gp120 and interferes with virus binding to $\mathrm{CD} 4^{+} \mathrm{T}$ cells. Peculiar is that PRO 2000 appears to be more active ( 10-fold) in inhibiting X4 viruses $\left(\mathrm{IC}_{50}: 1.9 \mu \mathrm{g} / \mathrm{ml}\right)$ compared to R5 viruses $\left(\mathrm{IC}_{50}: 20.8 \mu \mathrm{g} / \mathrm{ml}\right)$. Therefore, we investigated interactions of PRO 2000 with cellular HIV (co)-receptors.

\section{Methods}

Peripheral blood mononuclear cells (PBMCs) were incubated with PRO 2000 and flow cytometric assays performed using various fluorescent mAbs. Chemokineinduced signaling experiments were performed by FLIPR. Chemotaxis experiments were performed in $5-\mu \mathrm{m}$ pore transwell filter membranes. CXCL12 $2^{\mathrm{AF} 647}$ binding was monitored by flow cytometry. The Bio-Plex human cytokine 27-plex assay system was used for the detection of cytokines/chemokines in PBMCs.

\section{Results}

PRO 2000 dose-dependently interfered with the binding of several anti-CD4 mAbs (clone OKT4, Leu3a, SK3) and anti-CXCR4 (clone 2B11 and 12G5) in PBMCs, whereas minor or no effects were observed on DCSIGN and CCR5. The compound inhibited the CXCL12-induced signal transduction $\left(\mathrm{IC}_{50}: 19.9 \mu \mathrm{g} / \mathrm{ml}\right)$, CXCR4 internalization $\left(\mathrm{IC}_{50}: 9.5 \mu \mathrm{g} / \mathrm{ml}\right)$ and chemotaxis in PBMCs $\left(\mathrm{IC}_{50}: 6.7 \mu \mathrm{g} / \mathrm{ml}\right)$. It inhibited CXCL12 ${ }^{\mathrm{AF} 647}$ binding to $\mathrm{T}$ cells with an $\mathrm{IC}_{50}$ of $2.2 \mu \mathrm{g} / \mathrm{ml}$. PRO 2000 did not induce signaling by itself. These CXCR4 antagonistic properties of PRO 2000 are potential additional mechanism of action that could explain the observation that PRO 2000 is more active against X4 viruses. In addition, we also examined the cellular activation potential and cytokines profile of PRO 2000 in PBMCs. PRO 2000 had minor effects on the induction of the activation markers CD25, CD69 and HLA-DR on T cells, but it did enhance the production of a small number of cytokines/chemokines, and most dramatically the pro-

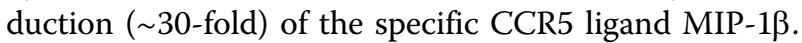

\section{Discussion}

Thus, PRO 2000 is not just a pure gp120 binding inhibitor to $\mathrm{CD}^{+} \mathrm{T}$ cells, but also interacts with CD4 and CXCR4 and can induce selective chemokines with potential anti-viral activity.

\section{Author details \\ ${ }^{1}$ Rega Institute for Medical Research, Leuven, Belgium. ${ }^{2}$ Indevus Pharmaceuticals, Lexington, USA.}

Published: 11 May 2010

doi:10.1186/1742-4690-7-S1-P17

Cite this article as: Huskens et al:: PRO 2000, a broadly active anti-HIV sulfonated compound, inhibits viral entry by multiple mechanisms. Retrovirology 2010 7(Suppl 1):P17.

* Correspondence: Dominique.Schols@rega.kuleuven.be

${ }^{1}$ Rega Institute for Medical Research, Leuven, Belgium 